CENDEKIA, Vol. 9, No. 2, Oktober 2015

p ISSN: 1978 2098; e ISSN: 2407 8557; Web: cendekia.pusatbahasa.or.id Pusat Kajian Bahasa dan Budaya, Surakarta, Indonesia

Santoso, Minto. 2015. Korelasi Penggunaan Media, Disiplin Belajar dan Motivasi Belajar terhadap Prestasi Belajar IPS. Cendekia, 9(2): 149 158.

\title{
KORELASI PENGGUNAAN MEDIA, DISIPLIN BELAJAR DAN MOTIVASI BELAJAR TERHADAP PRESTASI BELAJAR IPS
}

\author{
Minto Santoso \\ MI Hidayatul 'Ulum \\ Dayu Nglegok Blitar
}

Email: indonesia_sentosa@yahoo.com

\begin{abstract}
The objective of this study is to see relationship between learning media, learning discipline, and learning motivation toward learning achievement. The study used ex post facto design. Sample of this study was the 54 fifth and sixth graders of MI Hidayatul Ulum Dayu Nglegok Blitar. Data were analyzed using linear regression and porcessed using SPSS Windowsn Version 18. The findings of the study are there is linear relationship between: (1) media and learning achievement (.123 or $12.3 \%)$, (2) discipline and achievement (.329 or $32.9 \%)$, (3) learning motivation and achievement (.644 or $64.4 \%)$, and (4) media, discipline, motivation and achievement $.833(83 \%)$.
\end{abstract}

Keywords: media, motivation, achievement.

Menurut UU No 14 Tahun 2005 Tentang Guru Dan Dosen (2005:55), dinyatakan bahwa:Pembangunan nasional dalam bidang pendidikan adalah upaya mencerdaskan kehidupan bangsa dan

meningkatkan kualitas manusia Indonesia yang beriman, bertakwa, dan berakhlak mulia serta menguasai ilmu pengetahuan, teknologi, dan seni dalam mewujudkan masyarakat yang maju, adil, makmur, dan beradab berdasarkan Pancasila dan Undang-Undang Dasar Negara Republik Indonesia Tahun 1945.

Pendidikan dan pengajaran adalah suatu proses yang sadar tujuan. Tercapai tidaknya tujuan pengajaran salahsatunya adalah terlihat dari prestasi belajar yang diraih siswa. Dengan prestasi yang tinggi, parasiswa mempunyai indikasi berpengetahuan yang baik.Peran orang tua, masyarakat, instansi pemerintah dan guru sangatlah penting untuk mewujudkan pendidikan nasional. Guru sebagai pendidik dan pengajar merupakan faktor penentu kesuksesan setiap usaha pendidikan. Itulah sebabnya perbincangan mengenai pembaruan kurikulum, pengadaan alat-alat belajar sampai pada kriteria sumber daya manusia yang dihasilkan oleh pendidikan selalu bermuara pada guru. Hal ini betapa signifikan peran guru dalam dunia pendidikan (Syah, 2002:136).

Salah satu faktor yang mempengaruhi prestasi siswa adalah motivasi. Dengan adanyamotivasi, siswa akan belajar lebih keras, ulet, tekun dan memiliki konsentrasi penuhdalam proses belajar pembelajaran. Oleh karena itu,mutu prestasi belajar padasiswa perlu diperkuat terus-menerus. Dengan tujuan agar siswa memiliki motivasi belajar yangkuat, sehingga prestasi belajar yang diraihnya dapat optimal.Motivasi belajar yang dimiliki siswa 
CENDEKIA, Vol. 9, No. 2, Oktober 2015

p ISSN: 1978 2098; e ISSN: 2407 8557; Web: cendekia.pusatbahasa.or.id Pusat Kajian Bahasa dan Budaya, Surakarta, Indonesia

Santoso, Minto. 2015. Korelasi Penggunaan Media, Disiplin Belajar dan Motivasi Belajar terhadap Prestasi Belajar IPS. Cendekia, 9(2): 149 158.

dalam setiap kegiatan pembelajaran sangat berperanuntuk meningkatkan prestasi belajar siswa dalam mata pelajaran tertentu (Nashar, 2004:11).

Di samping itu proses belajar yang baik adalah proses belajar yang bisa memudahkan siswa dalam memahami materi pelajaran yang diajarkan. Sikap disiplin dalam belajar sangat diperlukan untuk terwujudnya suatu proses belajar yang baik. Sikap disiplin dalam belajar akan lebih mengasah keterampilan dan daya ingat siswa terhadap materi yang telah diberikan, karena siswa belajar menurut kesadarannya sendiri serta siswa akan selalu termotivasi untuk selalu belajar, sehingga pada akhirnya siswa akan lebih mudah dalam mengerjakan soal-soal dari materi yang diberikan. Pendidikan disiplin merupakan suatu proses bimbingan yang bertujuan untuk menanamkan pola perilaku tertentu, kebiasaan-kebiasaan tertentu, atau membentuk manusia dengan ciri-ciri tertentu, terutama untuk meningkatkan kualitas mental dan moral (Sukadji, 2002).

Mengingat proses pembelajaran adalah proses komunikasi maka guru memegang kunci yang dapat mengontrol efektifitas dan efesiensi komunikasi ini. Dengan semakin bertambahnya pengetahuan yang harus diberikan guru, bertambahnya tugas guru baik sosial dan ekonomi maka, harus ada jalan keluar untuk menjawab tantangan itu dengan penggunaan media pembelajaran. Media pembelajaran mempunyai peranan yang sangat penting dalam menunjang keberhasilan proses pembelajaran. Dengan adanya media pembelajaran akan menambah semangat dan pemahaman siswa terhadap materi yang diajarkan.Penggunaan media pembelajaran dalam pembelajaran IPS juga menjadi kesenangan sendiri bagi siswa. Selain itu, penggunaan media pembelajaran merupakan salah satu alternatif yang dianggap tepat, karena dalam penyajian materi pelajaran IPS siswa bukan hanya menerima secara teoritis, akan tetapi siswa dapat langsung mengamati bentuk dan gambar dari materi pelajaran IPS yang disajikan oleh guru.

Penggunaan media, disiplin belajarserta motivasi belajar siswa berperan penting dalam menentukan seberapa jauh siswa akan belajar dari suatu kegiatan pembelajaran atau seberapa jauh menyerap informasi yang disajikan kepada mereka. Berdasarkan latar belakang tersebut rumusan masalah yang diajukan adalah apakah ada korelasi antara (1) penggunaan media belajar terhadap prestasi belajar mata pelajaran Ilmu Pengetahuan Sosial Siswa kelas V dan Kelas VI MI Hidayatul 'Ulum Dayu, (2) disiplin belajar terhadap prestasi belajar Mata Pelajaran Ilmu Pengetahuan Sosial siswa kelas V dan kelas VI MI Hidayatul 'Ulum Dayu, (3) motivasi belajar terhadap prestasi belajar Mata Pelajaran Ilmu Pengetahuan Sosial siswa kelas V dan kelas VI MI Hidayatul 'Ulum Dayu, dan (4) penggunaan media belajar, disiplin belajar, dan motivasi belajar secara bersama-sama terhadap prestasi belajar mata pelajaran Ilmu Pengetahuan Sosial siswa kelas V dan kelas VI MI Hidayatul 'Ulum Dayu.

Uraian di atas didukung dengan landasan teoritis mengenai media, disiplin dan prestasi belajar. Media berasal dari bahasa latin merupakan bentuk jamak dari "Medium" yang secara harfiah berarti "perantara" atau "pengantar" yaitu perantara atau pengantar sumber pesan dengan penerima pesan. Dalam Proses belajar mengajar di kelas. Media berarti sebagai sarana yang berfungsi menyalurkan pengetahuan dari guru kepada peserta didik. Kelancaran aplikasi model pembelajaran sedikit banyak ditentukan pula oleh media pembelajaran yang digunakan. 
CENDEKIA, Vol. 9, No. 2, Oktober 2015

p ISSN: 1978 2098; e ISSN: 2407 8557; Web: cendekia.pusatbahasa.or.id Pusat Kajian Bahasa dan Budaya, Surakarta, Indonesia

Santoso, Minto. 2015. Korelasi Penggunaan Media, Disiplin Belajar dan Motivasi Belajar terhadap Prestasi Belajar IPS. Cendekia, 9(2): 149 158.

Media pembelajaran secara umum adalah alat bantu proses belajar mengajar. Segala sesuatu yang dapat dipergunakan untuk merangsang pikiran, perasaan, perhatian dan kemampuan atau keterampilanpembelajar sehingga dapat mendorong terjadinya proses belajar. Batasan ini cukup luas dan mendalam mencakup pengertian sumber, lingkungan, manusia dan metode yang dimanfaatkan untuk tujuan pembelajaran/ pelatihan.

Media memiliki beberapa fungsi. Pertama, media pembelajaran dapat mengatasi keterbatasan pengalaman yang dimiliki oleh para peserta didik. Pengalaman tiap peserta didik berbeda-beda, tergantung dari faktor-faktor yang menentukan kekayaan pengalaman anak, seperti ketersediaan buku, kesempatan melancong, dan sebagainya. Media pembelajaran dapat mengatasi perbedaan tersebut. Jika peserta didik tidak mungkin dibawa ke obyek langsung yang dipelajari, maka obyeknyalah yang dibawa ke peserta didik. Obyek dimaksud bisa dalam bentuk nyata, miniatur, model, maupun bentuk gambar-gambar yang dapat disajikan secara audio visual.

Kedua, media dapat melampaui batasan ruang kelas. Banyak hal yang tidak mungkin dialami secara langsung di dalam kelas oleh para peserta didik tentang suatu obyek, yang disebabkan, karena: (a) obyek terlalu besar; (b) obyek terlalu kecil; (c) obyek yang bergerak terlalu lambat; (d) obyek yang bergerak terlalu cepat; (e) obyek yang terlalu kompleks; (f) obyek yang bunyinya terlalu halus; (f) obyek mengandung bahan berbahaya dan resiko tinggi. Melalui penggunaan media yang tepat, maka semua obyek itu dapat disajikan kepada peserta didik. Selain itu, media memungkinkan adanya interaksi langsung antara peserta didik dengan lingkungannya, menghasilkan keseragaman pengamatan, menanamkan konsep dasar yang benar, konkrit, dan realistis, membangkitkan keinginan dan minat baru, membangkitkan motivasi dan merangsang anak untuk belajar, dan memberikan pengalaman yang integral/menyeluruh dari yang konkrit sampai dengan abstrak.

Adapun disiplin didefinisikan sebagai "Suatu tata tertib yang dapat mengatur tatanan kehidupan pribadi dan kelompok" (Djamarah, 2002:12). Prijodarminto (1994) dalam Tu'u (2004:31) menjelaskan disiplin adalah suatu kondisi yang tercipta dan berbentuk melalui proses dari serangkaian perilaku yang menunjukan nilai-nilai ketaatan, kepatuhan, kesetiaan, keteraturan dan keterikatan. Rachman (1999) dalam Tu'u (2004:32) menyatakan disiplin ialah upaya mengendalikan diri dan sikap mental individu atau masyarakat dalam mengembangkan kepatuhan dan ketaatan terhadap peraturan dan tata tertib berdasarkan dorongan dan kesadaran yang muncul dari dalam hatinya.

Kedisiplinan siswa dalam penelitian ini adalah keaktifan siswa dalam mengikuti pelajaran di kelas dan kaitannya dengan prestasi belajar yaitu: (1) Disiplin siswa dalam menentukan dan menggunakan cara atau strategi belajar, (2) Disiplin terhadap pemanfaatan waktu, (3) Disiplin terhadap tugas, dan (4) terhadap tata tertib.

Memperhatikan pendapat Reisman dan Payne dalam Mulyasa (2004:21) dapat dikemukakan sembilan strategi untuk mendisiplinkan peserta didik, sebagai berikut:

1) Konsep diri atau self-concept, strategi ini menekankan bahwa konsep diri masingmasing individu merupakan faktor penting dari setiap perilaku. 
2) Keterampilan berkomunikasi atau communication skill, guru harus memiliki keterampilan dalam berkomunikasi yang efektif agar mampu menerima semua perasaan, dan mendorong timbulnya kepatuhan peserta didik.

3) Konsekuensi logis dan alami atau natural and logical consequence, perilaku yang salah terjadi karena peserta didik telah mengembangkan kepercayaan yang salah terhadap dirinya.

4) Klarifikasi nilai atau values clarification, strategi ini dilakukan untuk membantu peserta didik dalam menjawab pertanyaannya sendiri tentang nilai-nilai dan membentuk sistem nilainya sendiri.

5) Analisis transaksional atau transactional analysis, disarankan agar guru belajara sebagai orang dewasa, terutama apabila berhadapan dengan peserta didik yang menghadapi masalah.

6) Terapi realistis atau reality therapy, sekolah harus berupaya mengurangi kegagalan dan meningkatkan keterlibatan. Dalam hal ini guru harus bersikap positif dan bertanggung jawab.

7) Disipin yang terintegrasi atau assertive discipline, metode ini menekankan pengendalian penuh oleh guru untuk mengembangkan dan mempertahankan peraturan.

8) Modifikasi perilaku atau behavior modification, perilaku salah yang disebabkan oleh lingkungan, sebagai tindakan remidiasi.

9) Tantangan bagi disiplin atau dare to discipline, guru diharapkan cekatan, sangat terorganisasi, dan dalam pengendalian yang tegas.

Menurut Mulyasa (2004:24), untuk mendisiplinkan peserta didik dengan sembilan strategi tersebut, harus mempertimbangkan berbagai situasi, dan memahami faktor-faktor yang mempengaruhinya. disarankan kepada guru untuk melakukan hal-hal sebagai berikut:

1) Mempelajari pengalaman peserta didik melalui kartu catatan kumulatif.

2) Mempelajari nama-nama peseta didik secara langsung, misalnya melalui daftar hadir dikelas.

3) Mempertimbangkan lingkungan pembelajaran dan lingkungan peserta didik.

4) Memberikan tugas yang jelas, dapat dipahami, sederahana, dan tidak rumit.

5) Menyiapkan kegiatan sehari-hari agar apa yang diakukan dalam pembelajaran sesuai dengan apa yang direncanakan, sehingga tidak terjadi penyimpangan.

6) Bergairah dan semangat dalam pembelajaran, dijadikan teladan peserta didik.

7) Berbuat sesuatu yang berbeda dan bervariasi, tidak monoton, sehingga membantu disiplin dan gairah belajar peserta didik.

8) Menyesuaikan argumentasi dengan kemampuan peserta didik, jangan memaksa peserta didik sesuai pemahaman guru, atau mengukur peserta didik dari kemampuan gurunya.

9) Membuat peraturan yang jelas dan tegas agar bisa diaksanakan dengan sebaik-baiknya oleh peserta didik dan lingkungannya. 
CENDEKIA, Vol. 9, No. 2, Oktober 2015

p ISSN: 1978 2098; e ISSN: 2407 8557; Web: cendekia.pusatbahasa.or.id Pusat Kajian Bahasa dan Budaya, Surakarta, Indonesia

Santoso, Minto. 2015. Korelasi Penggunaan Media, Disiplin Belajar dan Motivasi Belajar terhadap Prestasi Belajar IPS. Cendekia, 9(2): 149 158.

Apapun motivasi belajar adalah suatu perubahan tenaga di dalam diri seseorang (pribadi) yang ditandai dengan timbulnya perasaan dan reaksi untuk mencapai tujuan (Frederick J.Mc. Donald dalam Nashar, 2004:39). Tetapi menurut Clayton Aldelfer dalam Nashar (2004:42) motivasi belajar adalah kecenderungan siswa dalam melakukan kegiatan belajar yang didorong oleh hasrat untuk mencapai prestasi hasil belajar sebaik mungkin. Motivasi belajar juga merupakan kebutuhan untuk mengembangkan kemampuan diri secara optimum, sehingga mampu berbuat yang lebih baik, berprestasi dan kreatif (Abraham Maslow dalam Nashar, 2004:42) motivasi belajar adalah suatu dorongan internal dan eksternal yang menyebabkan seseorang atau individu untuk bertindak atau mencapai tujuan, sehingga perubahan tingkah laku pada diri siswa diharapkan terjadi.

Jadi motivasi belajar adalah kondisi psikologis yang mendorong siswa untuk belajar secara sungguh-sungguh, yang pada gilirannya akan terbentuk cara belajar siswa yang sistematis, penuh konsentrasi dan dapat menyeleksi kegiatan-kegiatannya. Menurut Sudirman (2008:83) fungsi motivasi belajar ada tiga yakni: (1) Mendorong manusia untuk berbuat sebagai penggerak atau motor yang melepaskan energi. Motivasi dalam hal ini merupakan motor penggerak dari setiap kegiatan yang akan dikerjakan; (2) Menentukan cara perbuatan yakni kearah tujuan yang hendak dicapai. Dengan demikian motivasi dapat memberikan arah dan kegiatan yang harus dikerjakan sesuai dengan rumusan tujuannya; dan (3) Menyeleksi perbuatan yakni menentukan perbuatan-perbuatan apa yang harus dikerjakan yang serasi guna mencapai tujuan, dengan menyisihkan perbuatan yang tidak bermanfaat dengan tujuan tersebut.

Hamlick (2003:161) juga mengemukakan tiga fungsi motivasi, yaitu: (1) Mendorong timbulnya kelakuan atau sesuatu perbuatan Tanpa motivasi maka tidak akan timbul suatu perbuatan seperti belajar, (2) Motivasi berfungsi sebagai pengarah, artinya menggerakan perbutan kearah pencapaian tujuan yang diinginkan, dan (3) Motivasi berfungsi penggerak, motivasi ini berfungsi sebagi mesin, besar kecilnya motivasi akan menentukan cepat atau lambatnya suatu pekerjaan atau perbuatan. Menurut Catharina Tri Ani (2006:186-187) ada beberapa strategi motivasi dalam belajar antara lain: membangkitkan minat belajar, mendorong rasa ingin tahu, dan membantu siswa dalam merumuskan tujuan belajar.

Pada umumnya prestasi diartikan sebagai apa yang dicapai secara maksimal dalam mengerjakan sesuatu. Ada yang berpendapat bahwa prestasi berasal dari bahasa Belanda "Pristatiej" yang kemudian diturunkan ke dalam bahasa Indonesia "Prestasi" yang berarti hasil usaha. Pendapat yang berbeda menyatakan bahwa prestasi adalah segala pekerjaan yang dicapai oleh manusia secara maksimal sehingga dapat menunjukkan kecakapan dari manusia.

Hasil belajar merupakan kemampuan yang diperoleh siswa setelah melakukan kegiatan belajar (Nashar, 2004:77). Hasil belajar adalah terjadinya perubahan dari hasil masukan pribadi berupa motivasi dan harapan untuk berhasil dan masukan dari lingkungan berupa rancangan dan pengelolaan motivasional tidak berpengaruh terhadap besarnya usaha yang dicurahkan oleh siswa untuk mencapai tujuan belajar (Keller dalam H Nashar, 2004:77). Seseorang dapat dikatakan telah belajar sesuatu apabila dalam dirinya telah terjadi perubahan, akan tetapi tidak semua perubahan yang terjadi. Jadi hasil belajar merupakan pencapaian tujuan dan hasil belajar sebagai produk dari proses belajar. 
CENDEKIA, Vol. 9, No. 2, Oktober 2015

p ISSN: 1978 2098; e ISSN: 2407 8557; Web: cendekia.pusatbahasa.or.id Pusat Kajian Bahasa dan Budaya, Surakarta, Indonesia

Santoso, Minto. 2015. Korelasi Penggunaan Media, Disiplin Belajar dan Motivasi Belajar terhadap Prestasi Belajar IPS. Cendekia, 9(2): 149 158.

\section{METODE}

Penelitian ini ialah penelitian dengan metode survei, tingkat eksplanation asosiatif dengan hubungan variabel kausal deskriptif, dengan rancangan penelitian korelasi untuk menguji hipotesis (hypothesis testing research). Penelitian ini menggunakan pendekatan kuantitatif dengan desain ex post facto. Penelitian ini mencari data empirik yang sistematik karena peneliti tidak dapat mengontrol langsung variabel bebas karena peristiwanya telah terjadi dan menurut sifatnya tidak dapat dimanipulasi.

Dilihat dari tingkat eksplanation, penelitian ini termasuk penelitian asosiatif dengan bentuk variabel kausal. Menurut Sugiyono (2006:11), "Penelitian asosiatif merupakan penelitian yang bertujuan untuk mengetahui hubungan antara dua variabel atau lebih". Sedangkan "hubungan kausal adalah bila X maka Y". Populasi penelitian ini adalah siswa kelas V dan VI MI Hidayatul 'Ulum Dayu Kec Nglegok Kab. Blitar sejumlah 54 siswa. Teknik yang digunakan pengumpulan data dalam penelitian ini adalah penyebaran angket dan dokumentasi. Data dianalisis menggunakan rumus korelasi product moment untuk menguji hipotesis pada taraf kesalahan 5\%. Teknik analisis data dalam penelitian ini menggunakan teknis analisis data regresi berganda dengan bantuan SPSS Windows versi 18. Adapun tahap pelaksananan analisis meliputi : (1) analisis deskriptif, (2) uji persyaratan analisis, (3) uji asumsi klasik, dan (4) uji hipotesis.

\section{HASIL DAN BAHASAN}

Berdasarkan hasil analisis data yang dilakukan maka pembahasan akan dilakukan untuk setiap hipotesis. Pada penelitian berjudul KorelasiPenggunaan Media,Disiplin BelajarDan Motivasi Belajar Terhadap Prestasi Belajar IPS Siswa Kelas V Dan Kelas VI MI Hidayatul 'Ulum Dayu I Kecamatan Nglegok Kabupaten Blitar memiliki empat hipotesis berikut:

\section{Pengaruh penggunaan media belajar terhadap prestasi belajar}

Penggunaan media belajar memiliki hubungan yang linier dengan prestasi belajar. Hal ini terbukti dengan besarnya sumbangan yang diberikan variabel penggunaan media terhadap prestasi belajar sebesar 0,123 atau 12,3\%.

\section{Pengaruh disiplin belajar terhadap prestasi belajar}

Disiplin belajar memiliki hubungan yang linier dengan prestasi belajar. Hal ini terbukti dengan besarnya sumbangan yang diberikan variabel disiplin belajar terhadap prestasi belajar sebesar 0,329 atau 32,9\%.

\section{Pengaruh motivasi belajar terhadap prestasi belajar}

Motivasi belajar memiliki hubungan yang linier dengan prestasi belajar. Hal ini terbukti dengan besarnya sumbangan yang diberikan variabel motivasi belajar terhadap prestasi belajar sebesar 0,644 atau 64,4\%. 
CENDEKIA, Vol. 9, No. 2, Oktober 2015

p ISSN: 1978 2098; e ISSN: 2407 8557; Web: cendekia.pusatbahasa.or.id Pusat Kajian Bahasa dan Budaya, Surakarta, Indonesia

Santoso, Minto. 2015. Korelasi Penggunaan Media, Disiplin Belajar dan Motivasi Belajar terhadap Prestasi Belajar IPS. Cendekia, 9(2): 149 158.

\section{Pengaruh menggunaan media belajar, disiplin belajar dan motivasi secara bersama- sama terhadap prestasi belajar.}

Secara keseluruhan diketahui bahwa penggunan media pembelajaran, tingkat disiplin siswa dan motivasi belajar memiliki hubungan yang linier dengan prestasi belajar yang mengikuti persamaan $\mathrm{Y}=11,869-0,117 \mathrm{x}_{1}+0,273 \mathrm{x}_{2}+0,702 \mathrm{x}_{3}$.Persamaan regresi tersebut dapat dijelaskan sebagai berikut:

a. Konstanta sebesar 11,869; artinya jika penggunan media $\left(\mathrm{X}_{1}\right)$, disiplin belajar siswa $\left(\mathrm{X}_{2}\right)$ dan motivasi belajar $\left(\mathrm{X}_{3}\right)$ nilainya adalah 0 , maka prestasi siswa (Y') nilainya adalah 11,87

b. Koefisien regresi variabel penggunan media $\left(\mathrm{X}_{1}\right)$ sebesar $-0,117$; artinya jika variabel independen lain nilainya tetap dan penggunaan media mengalami kenaikan $1 \%$, maka prestasi belajar (Y') akan mengalami penurunan sebesar 0,117 .

c. Koefisien regresi variabel disiplin belajar siswa $\left(\mathrm{X}_{2}\right)$ sebesar 0,273; artinya jika variabel independen lain nilainya tetap dan disiplin belajar mengalami kenaikan 1\%, maka prestasi belajar ( $\mathrm{Y}^{\prime}$ ) akan mengalami peningkatan sebesar 0.273 .

d. Koefisien regresi variabel motivasi belajar siswa $\left(\mathrm{X}_{2}\right)$ sebesar 0,702 ; artinya jika variabel independen lain nilainya tetap dan motivasi belajar mengalami kenaikan $1 \%$, maka prestasi belajar (Y') akan mengalami peningkatan sebesar 0.702 .

Analisis korelasi berganda ialah angka $\mathrm{R}$ sebesar 0,833 , menunjukkan bahwa terjadi hubungan yang sangat kuat antara penggunaan media belajar, disiplin belajar dan motivasi belajar terhadap hasil belajar. Disamping itu diperoleh angka $\mathrm{R}^{2}$ ( $\mathrm{R}$ Square) sebesar 0,694 atau $(69,4 \%)$. Hal ini menunjukkan bahwa prosentase sumbangan pengaruh variabel independen (penggunaan media belajar, disiplin belajar dan motivasi belajar) terhadap variabel dependen (prestasi belajar) sebesar 69,4\%. Atau variasi variabel independen yang digunakan dalam model (penggunaan media belajar, disiplin belajar dan motivasi belajar) mampu menjelaskan sebesar 69,4\%. variasi variabel dependen (prestasi belajar). Sedangkan sisanya sebesar $31,6 \%$ dipengaruhi oleh variabel lain.

\section{SIMPULAN}

Hasil analisis keempat variabel penelitian ini menunjukkan simpulan sebagai berikut:

1) Ada korelasi yang signifikan tentang penggunaan media belajar terhadap prestasi belajar mata pelajaran Ilmu Pengetahuan Sosial Siswa kelas V dan Kelas VI MI Hidayatul 'Ulum Dayu Kecamatan Nglegok Blitar Tahun Pelajaran 2014/2015, hal ini terbukti dengan besarnya sumbangan yang diberikan variabel penggunaan media terhadap prestasi belajar sebesar 0,123 atau $12,3 \%$.

2) Ada korelasi yang signifikan disiplin belajar terhadap prestasi belajar Mata Pelajaran Ilmu Pengetahuan Sosial siswa kelas V dan kelas VI MI Hidayatul 'Ulum Dayu Kecamatan Nglegok Blitar Tahun Pelajaran 2014/2015hal ini terbukti dengan besarnya sumbangan yang diberikan variabel disiplin belajar terhadap prestasi belajar sebesar 0,329 atau $32,9 \%$.

3) Ada korelasi yang signifikan motivasi belajar terhadap prestasi belajar Mata Pelajaran Ilmu Pengetahuan Sosial siswa kelas V dan kelas VI MI Hidayatul 'Ulum Dayu Kecamatan Nglegok Blitar Tahun Pelajaran 2014/2015, hal ini terbukti dengan besarnya 
CENDEKIA, Vol. 9, No. 2, Oktober 2015

p ISSN: 1978 2098; e ISSN: 2407 8557; Web: cendekia.pusatbahasa.or.id Pusat Kajian Bahasa dan Budaya, Surakarta, Indonesia

Santoso, Minto. 2015. Korelasi Penggunaan Media, Disiplin Belajar dan Motivasi Belajar terhadap Prestasi Belajar IPS. Cendekia, 9(2): 149 158.

sumbangan yang diberikan variabel motivasi belajar terhadap prestasi belajar sebesar 0,644 atau $64,4 \%$.

4) Ada korelasi yang signifikan tentang penggunaan media belajar, disiplin belajar, dan motivasi belajar secara bersama-sama terhadap prestasi belajar mata pelajaran Ilmu Pengetahuan Sosial siswa kelas V dan kelas VI MI Hidayatul 'Ulum Dayu Kecamatan Nglegok Blitar Tahun Pelajaran 2014/2015 persamaan Y $=11,869-0,117 \mathrm{x}_{1}+0,273 \mathrm{x}_{2}+$ $0,702 \mathrm{x}_{3}$.

5) Analisis korelasi berganda diperoleh angka $\mathrm{R}$ sebesar 0,833 . Hal ini menunjukkan bahwa terjadi hubungan yang sangat kuat antara penggunaan media belajar, disiplin belajar dan motivasi belajar terhadap hasil belajar. Disamping itu juga diperoleh angka $\mathrm{R}^{2}$ ( $\mathrm{R}$ Square) sebesar 0,694 atau $(69,4 \%)$. Hal ini menunjukkan bahwa prosentase sumbangan pengaruh variabel independen (penggunaan media belajar, disiplin belajar dan motivasi belajar) terhadap variabel dependen (prestasi belajar) sebesar 69,4\%\%. Atau variasi variabel independen yang digunakan dalam model (penggunaan media belajar, disiplin belajar dan motivasi belajar) mampu menjelaskan sebesar $69,4 \%$. variasi variabel dependen (prestasi belajar). Sedangkan sisanya sebesar 31,6\% dipengaruhi atau dijelaskan oleh variabel lain yang tidak dimasukkan dalam model penelitian ini.

\section{DAFTAR PUSTAKA}

Dimyati dan Mudjiono. 1994. Belajar Dan Pembelajaran. Jakarta. Depdikbud. Djamarah,Syaiful Bahri.Drs. 2002. Psikologi Belajar. Jakarta. PT Rieneka Cipta. Hamalik, Oemar. 2003. Prosedur Belajar Mengajar. Jakarta Bumi Aksara. Hamdani, M.A. 2010. Strategi Belajar Mengajar. Bandung. CV. Pustaka setia. Masnur, dkk. 2003. Dasar-dasar Interaksi Belajar Mengajar. Jakarta: Jemnars. Moedjiono. 1997. Proses Belajar Mengajar. Bandung: Remaja Rosdakarya.

Nashar, 2004. Peranan Motivasi dan Kemampuan awal dalam kegiatan pembelajaran. Jakarta: Delia press.

Ormrod, Jeanne E. 2008. Psikologi Pendidikan. Edisi keenam. Jakarta:Erlangga.

Purwanto, Ngalim. 2002. Psikologi Pendidikan. Bandung:Remaja Rosdakarya.

Purwodarminto, 1991. Strategi Belajar Mengajar . Jakarta: Bina Aksara

Sardiman. 2007. Interaksi dan motivasi belajar mengajar. Jakarta: PT. Raja Grafindo Persada Semiawan, Conny. 2008. Penerapan Pembelajaran pada Anak. Jakarta: Indeks. Slameto. 2010. Belajar dan Faktor-faktor yang mempengaruhi. Jakarta: PT. Rineka Cipta Sugiyono. 2006. Metode Penelitian Pendidikan, Alfabeta, bandung,.

........... 2012. Metode Penelitian Kuantitatif, Kualitatif, dan R\&D.Cetakan ke-17. Alfabeta. Bandung.

Suharsimi, Ari Kunto. 2010. Prosedur Penelitian Suatu Pendekatan Praktik. Rineka Cipta, Yogyakarta.

Syah, Muhibbin. 2013. Psikologi Pendidikan. Cet.ke-18. Bandung: Remaja Rosdakarya. Syaiful Bahri dan Djamarah, 1994. Prestasi Belajar dan Kompetensi Guru. Surabaya: Usaha Nasional.

Tu’u, Tulus. 2004. Peran Disiplin pada Perilaku dan Prestasi Siswa. Jakarta; Genesindo Usman, Moh. Uzer. 2000. Menjadi Guru Profesional. Bandung: Remaja Rosdakarya. 
CENDEKIA, Vol. 9, No. 2, Oktober 2015

p ISSN: 1978 2098; e ISSN: 2407 8557; Web: cendekia.pusatbahasa.or.id Pusat Kajian Bahasa dan Budaya, Surakarta, Indonesia

Santoso, Minto. 2015. Korelasi Penggunaan Media, Disiplin Belajar dan Motivasi Belajar terhadap Prestasi Belajar IPS. Cendekia, 9(2): 149 158.

Winataputra, S Udin. 2009. Teori Belajar dan Pembelajaran. Universitas Terbuka, Jakarta Yusuf, S. 1993. Dasar-dasar Pembinaan Kemampuan Proses Belajar Mengajar. Bandung: CV. Andria.

Andi-mustan.blogspot.com/2010/Faktor-penyebab-anak-malas belajar.html buku cooperative learning agus suprijono

http://akhmadsudrajat.wordpress.com/

http://digilib.unitomo.ac.id/gdl.php?mod=browse\&op=read\&id=jbptunitomo-

5ngy4qbbphgcxfuxgv4ewc3glifrvq-fifimurtab-300\&PHPSESSID=ordolinkrp http://mailzain.blogspot.com/ http://orenriffmilano.wordpress.com/2009/04/03/pengaruh-disiplin belajar-lingkungankeluarga-sekolah-terhadap-prestasi-belajar-siswa/ http://ridwan202.wordpress.com/2008/05/03/ketercapaian-prestasi-belajar/ http://sunartombs.wordpress.com/2009/01/05/pengertian-prestasi-belajar/ 
CENDEKIA, Vol. 9, No. 2, Oktober 2015

p ISSN: 1978 2098; e ISSN: 2407 8557; Web: cendekia.pusatbahasa.or.id Pusat Kajian Bahasa dan Budaya, Surakarta, Indonesia

Santoso, Minto. 2015. Korelasi Penggunaan Media, Disiplin Belajar dan Motivasi Belajar terhadap Prestasi Belajar IPS. Cendekia, 9(2): 149 158. 